\title{
$\mathrm{R}^{\text {juenal }} \mathrm{ECHSVINDING}$
}

\section{EKSISTENSI HUKUM ADAT DALAM PENYELENGGARAAN PEMERINTAHAN DESA DI BALI}

(Existence of Adat Law in the Governance Village in Bali)

\author{
Adharinalti \\ Badan Pembinaan Hukum Nasional Kementerian Hukum dan HAM RI \\ Jl. Mayjend Sutoyo - Cililitan Jakarta Timur \\ Email: adharinalti@gmail.com
}

Naskah diterima: 11 Desember 201; revisi: 14 Desember 2012; disetujui: 18 Desember 2012

\begin{abstract}
Abstrak
Melalui Pasal 18B Undang-Undang Dasar Negara Republik Indonesia Tahun 1945 (UUD NRI Tahun 1945), adat dan kesatuan masyarakat adat memiliki posisi yang istimewa dalam penyelenggaraan pemerintahan desa. Hal ini dikarenakan Desa sebagai penyelenggara pemerintahan yang langsung berhubungan dengan masyarakat. Salah satu daerah yang menarik untuk diteliti adalah Bali mengingat daerahnya yang sangat kental dengan adat dan hukum adatnya serta sebagai salah satu daerah yang memiliki desa adat (Desa Pakraman). Permasalahan yang muncul adalah bagaimana adat berinteraksi dalam penyelenggaraan pemerintahan desa di Bali? Jenis penelitiannya adalah kepustakaan dan empiris dengan studi dokumen dan wawancara dengan narasumber yang kompeten dibidangnya. Bahwa eksistensi adat dalam penyelenggaraan pemerintahan desa di Bali dapat terlihat dari diterapkannya konsep Tri Hita Karana dalam penyelenggaraan pemerintahan desa dengan salah satu bukti konkrit adalah adanya Desa Pakraman selain desa dinas.
\end{abstract}

Kata kunci: Hukum Adat, Masyarakat Hukum Adat, Pemerintahan Desa

\section{Abstract}

By Article 18B of the Constitution of the Republic of Indonesia Year 1945, the unity of indigenous peoples has a privileged position in village governance. This is because the village as the administrators who directly deal with the public. One interesting area to examine is the Bali given the highly viscous region with customs and customary law as well as one area that has a traditional village (Village Pakraman). The problem that arises is how to interact in a traditional village governance in Bali? Types of literature and empirical research is to study the documents and interviews to the informans. That the existence of indigenous peoples in village governance in Bali can be seen from the application of the concept of Tri Hita Karana in village governance with concrete evidence is one of the village but the village Pakramanservice.

Keywords: Adat Law, Indigenous People, Village Government 


\section{A. Pendahuluan}

Semenjak reformasi tahun 1998, terjadi perubahan konstitusi yang berdampak pada perubahan peraturan yang mengatur tentang pemerintahan daerah. Konstitusi perubahan tersebut diberi nama Undang-Undang Dasar Negara Republik Indonesia Tahun 1945 (UUD NRI Tahun 1945). Melalui Pasal 18 B UUD NRI Tahun 1945, negara dengan tegas mengakui dan menghormati satuan-satuan pemerintahan daerah yang bersifat khusus atau bersifat istimewa serta mengakui dan menghormati kesatuan-kesatuan masyarakat hukum adat beserta hak-hat istimewa tradisionalnya sepanjang masih hidup dan sesuai dengan perkembangan masyarakat dan prinsip Negara Kesatuan Republik Indonesia.

Hal ini berarti desa-desa yang dahulu sudah ada sebelum masuknya penjajah harus diakui dan dihormati oleh negara. Mereka merupakan organisasi komunitas lokal yang mempunyai batas-batas wilayah, dihuni oleh sejumlah penduduk, dan mempunyai adatistiadat untuk mengelola dirinya sendiri (selfgoverning community). Sebutan Desa sebagai kesatuan masyarakat hukum baru dikenal pada masa kolonial Belanda. Desa pada umumnya mempunyai pemerintahan sendiri yang dikelola secara otonom tanpa ikatan hirarkhis-struktural dengan struktur yang lebih tinggi. Di Sumatera Barat, misalnya, nagari adalah sebuah "republik kecil" yang mempunyai pemerintahan sendiri secara otonom dan berbasis pada masyarakat. ${ }^{1}$
Guna menjalankan amanat Pasal 18B UUD NRI Tahun 1945, diberlakukan Undang-Undang Nomor 32 Tahun 2004 tentang Pemerintahan Daerah (UU Pemda). Melalui UU Pemda ini, Desa tidak termasuk dalam skema desentralisasi teritorial. UU Pemda tidak mengenal otonomi Desa, melainkan hanya mengenal otonomi daerah. ${ }^{2}$ Pengaturan tentang Desa dimuat dalam Bab XI Pasal 200 sampai Pasal 216 UU Pemda dan Peraturan Pemerintah No. 72 Tahun 2005 tentang Pedoman Umum Pengaturan Mengenai Desa (PP No. 72/2005).

Menurut UU Pemda, Desa adalah kesatuan masyarakat hukum yang memiliki batas-batas wilayah yang berwenang untuk mengatur dan mengurus kepentingan masyarakat setempat, berdasarkan asal-usul dan adat istiadat setempat yang diakui dan dihormati dalam sistem Pemerintahan Negara Kesatuan Republik Indonesia. Selanjutnya, ada empat urusan pemerintahan desa menurut Pasal 206 UU Pemda, yaitu:

a. urusan yang sudah ada berdasarkan hak asal-usul Desa;

b. urusanyangmenjadikewenangankabupaten/ kota yang diserahkan pengaturannya kepada Desa;

c. tugas pembantuan dari Pemerintah, provinsi, dan/atau pemerintah kabupaten/kota;

d. urusan lainnya yang oleh peraturan perundang-perundangan diserahkan kepada Desa.

Pengakuan dari konstitusi dan peraturan perundang-undangan tersebut memberikan

Naskah Akademis Rancangan Undang-Undang tentang Desa (Jakarta: Direktorat Jenderal Pemberdayaan Masyarakat dan Desa - Departemen Dalam Negeri, 2007), hlm. 11.

2 Indonesia. Undang-Undang tentang Pemerintahan Daerah. UU No.32. LN No.125 Tahun 2004. TLN. No.4437.

3 Dengan diterbitkannya Undang-Undang Nomor 8 Tahun 2005 tentang Penetapan Peraturan Pemerintah Pengganti Undang-Undang Nomor 3 Tahun 2005 tentang Perubahan Atas Undang-Undang Nomor 32 Tahun 2004 tentang Pemerintahan Daerah Menjadi Undang-Undang dan maka PP No. 76/2001 diganti dengan Peraturan Pemerintah No. 72 Tahun 2005 tentang Desa. 


\section{$\mathrm{R}_{\text {juknaL }}^{\text {juTSVINDING }}$

posisi yang istimewa kepada kesatuan-kesatuan masyarakat hukum adat penyelenggaraan pemerintahan terutama pemerintahan desa. Hal ini dikarenakan, desa sebagai penyelenggara pemerintahan yang langsung berhubungan dengan masyarakat. Namun dalam konteks empiris, muncul sejumlah pertanyaan yang berhulu pada ada atau tidak adanya peran adat dalam penyelenggaraan pemerintahan desa tersebut.

Dalam konteks implementatif menunjukan, bahwa di daerah-daerah ada hubungan yang khas antara penerapan adat dan penyelenggaran pemerintahan desa. Di Papua, lembaga adat sangat dominan sedangkan desa dinas tidak memiliki pengaruh. Berbeda dengan di Jawa, sebagian besar Sulawesi, Kalimantan Timur, dan sebagianSumatera, didaerah tersebut, pengaruh adat sangat kecil. Desa dinas sudah tumbuh kuat. Di Sumatera Barat terjadi kompromi antara adat dan desa dinas, karenakan lembaga adat dan desa dinas sama-sama kuat. Di Bali, seperti juga di Kalimantan Barat, Aceh, Nusa Tenggara Timur, dan Maluku, pengaruh lembaga adat jauh lebih kuat ketimbang Desa Dinas. ${ }^{4}$

Dalam penelitian ini salah satu daerah yang menarik untuk diteliti adalah Bali. Hal ini mengingat Bali sangat kental dengan adat dan hukum adatnya serta sebagai salah satu daerah yang memiliki desa adat (Desa Pakraman) selain desa dinas.

\section{B. Permasalahan}

Berdasarkan latar belakang tersebut di atas, maka rumusan masalah yang akan diteliti adalah bagaimana eksistensi hukum adat dalam penyelenggaraan pemerintahan desa di Bali?

\section{Metode Penelitian}

Tipe penelitian ini adalah penelitian kepustakaan (penelitian hukum normatif) dan penelitian lapangan. Penelitian hukum normatif merupakan bentuk penelitian kepustakaan (library research) untuk memperoleh data kepustakaan berupa bahan hukum primer, sekunder, dan tersier. Pendekatan normatif ini relevan guna menganalisis norma-norma hukum adat yang hidup dan berlaku dalam penyelenggaraan pemrintahan desa. Untuk data primer dalam penelitian empiris ini didapat melalui wawancara pada tanggal 14 Juni 2011 sebagai bahan pendukung data sekunder. Sifat penelitian yang dilakukan adalah penelitian deskriptif. Penelitian deskriptif ini untuk memberikan gambaran tentang eksistensi adat dalam penyelenggaraan pemerintahan desa di Bali.

Penelitian hukum melalui penelitian kepustakaan (library research) dilakukan melalui studi dokumen untuk mendapatkan data sekunder, berupa bahan hukum primer, yaitu UUD NRI Tahun 1945, peraturan perundangundangan yang terakit dengan hukum adat dan pemerintahan desa, bahan hukum sekunder berupa Naskah Akademis Rancangan UndangUndang tentang Desa, jurnal, hasil penelitian sebelumnya, buku-buku dan artikel-artikel yang berkaitan dengan permasalahan yang diteliti, serta bahan hukum tersier berupa kamus dan ensiklopedia berupa data kepustakaan. Sedangkan untuk data primernya dilakukan melalui wawancara dengan I Made Gede Wijaya (Kepala Desa Padangsambian Kaja) dan Dewa Eka (Kepala Biro Hukum Pemerintah Daerah Propinsi Bali).

Peraturan Pemerintah tentang Desa. PP No.72. LN No. 158 Tahun 2005. TLN. No. 4587. 
Metode analisa data yang digunakan dalam penelitian hukum ini adalah metode analisis kualitatif. Data sekunder dan primer yang berkaitan dengan hukum adat dan pemerintahan desa ini diolah secara kualitatif dengan menggunakan teori pengakuan atau rekognisi negara terhadap satuan pemerintahan daerah yang bersifat khusus atau istimewa dan kesatuan-kesatuan masyarakat hukum adat beserta hak-hak tradisionalnya sebagai mana amanat Pasal 18B UUD NRI Tahun 1945 sebagai pisau analisanya.

\section{PEMBAHASAN}

\section{Sistem Pemerintahan Desa di Bali}

Bali, pulau mungil yang memiliki keunikan tersendiri. Berbagai julukan telah diberikan kepada pulau yang memikat ini diantaranya adalah, The Last Paradise on Earth (Sorga terakhir bumi), The morning of the Word (Paginya dunia), The Island of Gods (Pulau dewata), The Intresting Peacefull Island (Pulau penuh kedamaian yang sangat mempesona), dan seseorang ahli purbakala bernama Bernet Kempers menyebutnya dengan Land of One Thousand Temples (pulau dengan seribu pura). Kenyataanya menurut ahli purbakala ini, jumlah pura di Bali lebih dari 20.000 buah.

Hubungan antara agama Hindu dan budaya Bali adalah ibarat tenunan benang pada kain endek Bali, yang sudah saling jalin-menjalin dengan warna dan coraknya yang khas. Dalam hubungannya dengan kebudayaan Bali, agama Hindu memancar pada pandangan hidup masyarakat Bali yang pengejawantahannya terlihat pada organisasi sosial kemasyarakatan tradisional seperti desa Adat, Subak dan lainlain.

Desa Adat yang sekarang dikenal, pada mulanya dikenal dengan sebutan 'desa' saja. Tetapi dengan adanya pembentukan desa yang lain oleh pemerintah Belanda, yang mempunyai tugas khusus dalam penanganan administrasi pemerintah ditingkat bawah, maka terjadilah kerancuan pengertian 'desa'. Oleh karena itu untuk memberikan pembedaan yang tegas maka desa yang berbeda fungsi dan tugasnya tersebut diberi nama masing-masing 'Desa Adat' dan 'Desa Dinas' atau 'Desa Administratif'.

Eksistensi desa adat, secara yuridis formal tertuang dalam Peraturan Daerah Propinsi Bali Nomor 6 Tahun 1986 tentang Kedudukan, Fungsi, dan Peranan Desa Adat sebagai Kesatuan Masyarakat Hukum Adat dalam Propinsi Daerah Tingkat I Bali (selanjutnya disebut dengan Perda Desa Adat). Di dalam Pasal 1 (e) Perda Desa Adat, manyatakan bahwa: 6

Desa Adat adalah "Kesatuan masyarakat hukum adat di Propinsi Daerah Tingkat I Bali yang mempunyai satu kesatuan tradisi dan tata krama pergaulan hidup masyarakat umat Hindu secara turun temurun dalam ikatan Kahyangan Tiga (Kahyangan Desa) yang mempunyai wilayah tertentu dan harta kekayaan sendiri serta berhak mengurus rumah tangganya sendiri".

Namun dengan berkembangnya masyarakat dan terjadinya perubahan sosial yang demikian cepat serta dicabutnya Undang-Undang Nomor 5 Tahun 1974 tentang Poko-Pokok Pemerintahan di Daerah dan Undang-Undang Nomor 5 Tahun 1979 tentang Pemerintahan Desa, dipandang

I Made Titib, "Desa Pakraman Wahana Pengamalan Ajaran Agama Hindu Di Bali," http://www.hukumhindu. com/2011/03/hukum-adat/. (diakses 6 Agustus 2011).

6 Peraturan Daerah Propinsi Bali Nomor 6 Tahun 1986 tentang Kedudukan Fungsi dan Peranan Adat sebagai Kesatuan Masyarakat Hukum Adat Dalam Propinsi Daerah Tingkat I Bali. 


\section{RECHTSVINDING \\ Media Pembinaan Hukum Nasional}

Volume 1 Nomor 3, Desember 2012

perlu untuk mengadakan perubahan terhadap Perda Desa Adat sesuai dengan perkembangan dan perubahan sosial yang terjadi di Bali. ${ }^{7}$

Dalam upaya mengadakan perubahan terhadap Perda Desa Adat, telah diganti dengan Peraturan Daerah tentang Desa Pakraman, mengingat "pakraman" telah dipergunakan sejak adanya desa adat di Bali. Peraturan Daerah tersebut bernama Peraturan Daerah Propinsi Bali Nomor 3 Tahun 2001 tentang Desa Pakraman. ${ }^{8}$ Dengan demikian maka istilah Desa Adat berganti menjadi Desa Pakraman.

Pasal 1 angka 4 Perda Desa Pakraman, menyebutkan bahwa Desa Pakraman adalah kesatuan masyarakat hukum adat di Propinsi Bali yang mempunyai satu kesatuan tradisi dan tata karma pergaulan hidup masyarakat umat Hindu secara turun temurun dalam ikatan kahyangan tiga atau kahyangan desa yang mempunyai wilayah tertentu dan harta kekayaan sendiri serta berhak mengurus rumah tangganya sendiri.

Hal ini menunjukkan bahwa Desa Pakraman adalah desa sebagai wahana aktivitas umat Hindu di daerah ini. Sebagai tindak lanjut dari Peraturan Daerah Bali tersebut didirikan Majelis Utama Desa Pakraman, di tingkat provinsi dan Majelis Madya Desa Pakraman di tingkat kabupaten dan kota, dan di tingkat kecamatan disebut Majelis Alit Desa Pakraman yang mempunyai fungsi antara lain memelihara dan mengembangkan kehidupan beragama Hindu di daerah Bali, melestarikan seni budaya dan adat istiadat yang merupakan warisan leluhur.
Desa Adat dengan Banjar-Banjarnya adalah lembaga masyarakat umat Hindu yang sepenuhnya berdasarkan keagamaan. Secara nyata dasar keagamaan itu dapat dilihat pada Kahyangan Tiga dan upacara-upacara agama yang berlangsung di Desa Adat seperti upacara Tawur Kesanga, Usabha Desa dan lain-lain. Agama Hindu menjiwai dan meresapi segala kegiatan Krama Desa.

Demikian pula jika dikaji ajaran agama tentangupayauntukmewujudkankesejahteraan, kemakmuran dan kebahagiaan hidup serta membina hubungan harmonis antara manusia yang kemudian dikenal dengan Tri Hita Karana, maka Desa Adat tidak saja merupakan persekutuan teritorial dan persekutuan hidup atas kepentingan bersama dalam masyarakat, tetapi juga merupakan persekutuan dalam kesamaan agama dalam memuja Tuhan Yang Maha Esa. Perpaduan ketiga unsur-unsur Tri Hita Karana, yakni mewujudkan hubungan antara manusia dengan Tuhan Yang Maha Esa dengan mendirikan pura Kahyangan Tiga atau Kahyangan-Kahyangan Desa, mewujudkan hubungan yang harmonis antar sesama manusia yang bertempat tinggal sama dalam suatu desa melalui aturan yang berlaku sebagai anggota Desa Adat atau Krama Desa dan membina hubungan yang harmonis dengan alam lingkungan dalam wilayah yang sama yakni wilayah Desa Pakraman dengan pemeliharaan bersama desa, fasilitas desa dan Banjar masingmasing dengan baik dengan Parareman atau Pasangkepan rutin. Dengan demikian Tri Hita

Perda Desa Pakaraman ini keluar menyusul diundangkannya Undang-undang No. 22 Tahun 1999 tentang Pemerintahan Daerah, yang menyatakan bahwa dalam penyelenggaraan otonomi daerah sesuai dengan asas desentralisasi diarahkan pada prinsip-prinsip demokrasi, peran serta masyarakat, pemerataan, dan keadlian, serta memperhatikan potensi dan keanekaragaman daerah yang menghormati kesatuan masyarakat hukum yang menghormati hak asal usul yang bersifat istimewa.

8 Peraturan Daerah Propinsi Bali Nomor 3 Tahun 2001 tentang Desa Pakraman. (Lembar Daerah Provinsi Bali Tahun 2001 No. 29 Seri D no. 29. Tambahan Lembar Daerah Propinsi Bali Tahun 2001). 
Karana, yang menyebabkan kehidupan yang harmonis antara sesama warga Desa Pakraman untuk mewujudkan kesejahteraan dan kebahagiaan hidup merupakan landasan bagi Desa Pakraman. ${ }^{9}$

Fungsi Desa Pakraman yang paling menonjol bagi warga atau Krama-nya, adalah untuk bersama-sama meringankan beban kehidupan baik suka dan duka (dalam Pasuka-dukan Desa). Dengan demikian fungsi atau peranan Desa Pakraman dalam pelaksanaan Agama Hindu secara lebih detail dapat juga dirinci sebagai berikut mengatur hubungan Krama Desa dengan Kahyangan, mengatur pelaksanaan Pañca Yajña dalam masyarakat, mengatur penguasaan Setra, mengatur hubungan antar sesama Krama Desa, mengurusi tanah, sawah dan barang-barang lainya milik Desa Pakraman, menetapkan sanksisanksi bagi pelanggaran terhadap hukum Adat (awig-awig), menjaga keamanan, ketertiban dan kedamaian masyarakat, memberikan perlindungan hukum bagi Krama Desa, mengikat persatuan dan kesatuan antar sesama Krama Desa dengan cara gotong royong dalam bidang ekonomi, teknologi, kemasyarakatan dan keagamaan, menjunjung dan mensukseskan program pemerintah. ${ }^{10}$

Selain desa Pakraman, di Bali juga ada desa dinas dan kelurahan. Sebagaimana diketahui, dalam sistem pemerintahan daerah, desa merupakan struktur pemerintahan terkecil. Desa atau yang disebut dengan nama lain, selanjutnya disebut desa, menurut Pasal 1 angka 5 PP tentang Desa, adalah kesatuan masyarakat hukum yang memiliki batas-batas wilayah yang berwenang untuk mengatur dan mengurus kepentingan masyarakat setempat, berdasarkan asal-usul dan adat istiadat setempat yang diakui dan dihormati dalam sistem Pemerintahan Negara Kesatuan Republik Indonesia.

Secara histori, desa dinas di Bali terbentuk dari keperbekelan. Bahwa pada zaman kerajaan, raja-raja Bali telah membentuk keperbekelan. Pembentukan keperbekelan ini adalah sebagai penghubung antara kerajaan dengan desa adat (desa pakraman). Pada waktu itu yang namanya pemerintahan adalah raja. Raja pada zamannya selalu mendapatkan upeti dari rakyatnya. Keperbekelan inilah yang mengurusi pemerintahan (dalam hal ini termasuk juga upeti raja). Selanjutnya, keperbekelan menjadi cikal bakal desa dinas. Sedangkan desa pakraman mengurusi persoalan adat istiadat dan budaya Bali berdasarkan agama Hindu.

Dalam menjalankan roda pemerintahannya, desa dinas di Bali tunduk pada peraturan perundang-undangan dan hukum adat yang hidup dan masih berlaku di wilayah tersebut. Menurut Dewa Eka (Kepala Biro Hukum Pemerintah Daerah Propinsi Bali), ada sekitar 700-an desa dinas di Bali. ${ }^{11}$ Berdasarkan struktur kepemerintahannya, desa (dinas) berada di bawah kecamatan. Di Bali, selain desa (dinas) juga ada kelurahan yang berdasarkan struktur kepemerintahannya, sama-sama berada di bawah kecamatan. Jadi dalam satu kecamatan di Bali, ada desa dan ada kelurahan. Dalam satu desa di Bali terdapat beberapa dusun. Juga ditemukan ada beberapa banjar pakraman 


\section{$\mathrm{R}_{\text {juknaL }}^{\text {juTSVINDING }}$

yang urusan kedinasannya (kependudukannya) berada dalam satu dusun.

Berbeda dengan desa pakraman, desa (dinas) bertugas di luar urusan adat dan keagamaan, misalnya dalam hal menjalankan urusan pemerintahan desa termasuk administrasi warga/masyarakat Bali. Jika warga Bali, misalnya akan membuat KTP dan akta kelahiran, mereka harus mengurusnya ke pemerintah desa (dinas), bukan ke desa pakraman. Akan tetapi jika salah satu warga Bali akan melakukan upacara perkawinan atau upacara ngaben misalnya, maka urusan tersebut menjadi kewenangan desa pakraman.

Salah satu urusan pemerintahan desa yang tertuang dalam Pasal 206 UU Pemda dan Pasal 7 sampai Pasal 10 PP No. 72 Tahun 2005 adalah urusan yang sudah ada berdasarkan hak asal-usul Desa. Di Desa Padangsambian Kaja, menurut Kepala Desa I Made Gede Wijaya, aplikasi desa menjalankan urusan yang sudah ada berdasarkan hak asal-usul desa ada pada proses penetapan Kepala Desa. Desadesa yang berada dalam wilayah hukum Kota Denpasar, dalam hal pemilihan, pencalonan, pengangkatan, pelantikan dan pemberhentian serta pengangkatan penjabat kepala desa, tunduk pada Peraturan Daerah Kota Denpasar No.3Tahun 2007 tentangPemilihan, Pencalonan, Pengangkatan, Pelantikan dan Pemberhentian serta Pengangkatan Penjabat Kepala Desa (yang selanjutnya disebut dengan Perda Kota Denpasar tentang Tatacara Pemilihan Kades).

Dalam pelaksanaannya, persyaratan tersebut haruslah memperhatikan nilai-nilai sosial budaya dan adat istiadat kesatuan masyarakat hukum adat setempat. Menurut keterangan Kepala Desa Padangsambian Kaja, bahwa ada nilai-nilai yang sudah menjadi tradisi di desanya dalam proses penentuan calon kepala desa di wilayah tersebut, yaitu berdasarkan pada aspirasi warga atau masyarakat dusun di wilayah hukum Desa Padangsambian Kaja. Masyarakat akan menolak calon kepala desa yang menurut masyarakat di dusun tersebut tidak layak untuk menjadi kepala desa mereka meskipun syarat-syarat formil yang ditentukan oleh peraturan perundangundangan sudah terpenuhi. Aspirasi para warga dusun haruslah menjadi perhatian dalam proses pemilihan kepala desa, dikarenakan desa tersebut sudah ada terlebih dahulu sebelum adanya peraturan tersebut. Negara pun harus menghormati nilai-nilai sosial budaya dan adat istiadat kesatuan masyarakat hukum adat setempat yang masih hidup itu. ${ }^{12}$

\section{Penerapan Hukum Adat Dalam Penyelenggaraan Pemerintahan Desa di Bali}

Hukum adat merupakan sistem hukum yang dikenal dalam lingkungan kehidupan sosial di Indonesia dan negara-negara Asia lainnya seperti Jepang, India, dan Tiongkok. Sumbernya adalah peraturan-peraturan hukum tidak tertulis yang tumbuh dan berkembang dan dipertahankan dengan kesadaran hukum masyarakatnya. Mengingat peraturan-peraturan ini tidak tertulis dan tumbuh kembang, maka hukum adat memiliki kemampuan menyesuaikan diri dan elastis. Selain bersifat tidak tertulis, hukum adat juga ada yang bersifat tercatat (beschreven), seperti yang dituliskan oleh para penulis sarjana hukum yang cukup terkenal di Indonesia, dan hukum adat yang didokumentasikan (gedocumenteerch) seperti dokumentasi awigawig di Bali.

\footnotetext{
12 Hasil wawancara dengan I Made Gede Wijaya (Kepala Desa Padangsambian Kaja) pada tanggal 14 Juni 2011.
} 
Istilah Hukum Adat pertama kali diperkenalkan secara ilmiah oleh Prof. Dr. C Snouck Hurgronje. Kemudian pada tahun 1893, Prof. Dr. C. Snouck Hurgronje dalam bukunya yang berjudul "De Atjehers" menyebutkan istilah hukum adat sebagai "adat recht" (bahasa Belanda) yaitu untuk memberi nama pada satu sistem pengendalian sosial (social control) yang hidup dalam masyarakat Indonesia. Istilah ini kemudian dikembangkan secara ilmiah oleh Cornelis van Vollenhoven yang dikenal sebagai pakar Hukum Adat di Hindia Belanda (sebelum menjadi Indonesia).

Dalam penyelenggaraan pemerintahan desa, hukum adat dapat terlihat dari produk hukumnya. Beberapa produk hukum yang mengakomodir dan melegalkan hukum adat dalam penyelenggaraan pemerintahan desa di Bali, antara lain: a) Peraturan Daerah Propinsi Bali No. 6 Tahun 1986 tentang Kedudukan, Fungsi, dan Peranan Desa Adat sebagai Kesatuan Masyarakat Hukum Adat dalam Propinsi Daerah Tingkat I Bali (Perda Desa Adat); b) Peraturan Daerah Propinsi Bali No. 3 Tahun 2001 tentang Desa Pakraman; c) Peraturan Daerah Kota Denpasar No. 1 Tahun 2009 tentang Rencana Pembangunan Jangka Panjang Daerah Tahun 2005-2025; dan d) Surat Keputusan Bersama Bendesa Adat Pakraman Padangsambian dengan Kepala Kelurahan Padangsambian, Kepala Desa Padangsambian Kaja, Kepala Padangsambian Kelod.

Menurut International Labour Organization (ILO), sedikitnya terdapat 5.000 kelompok masyarakat hukum adat dengan jumlah penduduk mencapai lebih dari 370 juta, menempati 70 negara, termasuk Indonesia. Dengan sekitar 1.072 beragam kelompok etnis, termasuk 11 kelompok etnis dengan populasi lebih dari satu juta orang. Indonesia termasuk salah satu negara dengan budaya paling beragam di dunia. ${ }^{13}$

Indonesia memiliki sistem hukum yang beragam selain hukum negara. Masing-masing sistem hukum itu memiliki kekuatan mengikat pada tiap kelompokmasyarakattermasukhukum adat yang mengikat bagi masyarakat hukum adatnya. Masyarakat hukum adat memiliki budaya, tradisi dan adat-istiadat tersendiri. Hal inilah yang membuat hukum adat yang hidup dan berkembang di Indonesia memiliki keanekaragaman dan keunikan tersendiri, salah satu contohnya adalah di Bali.

Balidan masyarakatnya menjalani keseharian mereka dengan tata kehidupan, agama, seni, dan budaya yang unik. Keunikan inilah kemudian, pada sekitar tahun 1579, menjadi perhatian seorang Belanda bernama Cornelis de Houtman yang melakukan perjalanan ke Indonesia untuk mencari rempah-rempah. Tanah yang subur, kegiatan pertanian dan keunikan budaya penduduknya dalam menjalani keseharian sungguh menjadi perhatian besar bagi ekspedisi de Houtman. ${ }^{14}$

Keyakinan umat Hindu terhadap keberadaan Tuhan/Hyang Widhi yang Wyapi Wyapaka atau ada di mana-mana juga di dalam diri sendiri merupakan tuntunan yang selalu mengingatkan keterkaitan antara karma atau perbuatan dan pahala atau akibat, yang menuntun prilaku manusia ke arah Tri Kaya Parisudha sebagai terpadunya manacika, wacika, dan kayika atau

\footnotetext{
ILO, "Mengkaji Hak Masyarkat Hukum Adat di Indoensia," http://www.ilo.org/jakarta/info/public/pr/lang--en/ contLang--id/WCMS_116136/index.htm. (diakses 13 September 2011).

14 Bali dan Pariwisata". http://www.baliprov.go.id/index.php?page=69. Diunduh pada tanggal 13 September 2011.
} 


\section{$\mathrm{R}_{\text {juknaL }}^{\text {juTSVINDING }}$

penyatuan pikiran, perkataan, dan perbuatan yang baik.

Umat Hindu percaya bahwa alam semesta beserta segala isinya adalah ciptaan Tuhan sekaligus menjadi karunia Tuhan kepada umat manusia untuk dimanfaatkan guna kelangsungan hidup mereka. Karena itu tuntunan sastra Agama Hindu mengajarkan agar alam semesta senantiasa dijaga kelestarian dan keharmonisannya yang dalam pemahamannya diterjemahkan dalam filosofi Tri Hita Karana sebagai tiga jalan menuju kesempurnaan hidup, yaitu:

a. Hubungan manusia dengan Tuhan; sebagai atma atau jiwa dituangkan dalam bentuk ajaran agama yang menata pola komunikasi spiritual lewat berbagai upacara persembahan kepada Tuhan. Oleh karena itu, dalam satu komunitas masyarakat Bali yang disebut Desa Adat dapat dipastikan terdapat sarana Parhyangan atau Pura, disebut sebagai Kahyangan Tiga, sebagai media dalam mewujudkan hubungan manusia dengan Ida Sang Hyang Widhi.

b. Hubungan manusia dengan alam lingkungannya; sebagai angga atau badan tergambar jelas pada tatanan wilayah hunian dan wilayah pendukungnya (pertanian) yang dalam satu wilayah Desa Adat disebut sebagai Desa Pakraman.

c. Hubungan manusia dengan sesama manusia; sebagai khaya atau tenaga yang dalam satu wilayah Desa Adat disebut sebagai Krama Desa atau warga masyarakat, adalah tenaga penggerak untuk memadukan atma dan angga.

Dalam praktek, ada kerjasama yang baik antara pemerintahan desa (dinas) dengan Desa Pakraman. Salah satunya dapat terlihat dari Surat Keputusan Bersama Bendesa Desa Pakaraman
Padangsambian dengan Kepala Kelurahan Padangsambian, Kepala Desa Padangsambian Kaja, Kepala Desa Padangsambian Kelod nomor 12/U/Kep./DP.Pds/2005 tentang Pengenaan Retribusi Pedagang di Luar Areal Pasar Desa Pakraman Padangsambian tertanggal 30 Januari 2005. Dalam salah satu pertimbangannya, keputusaninihadirsehubungan dengan besarnya pengeluaran dana untuk pembayaran upacara/ upakara untuk merahayukan Desa (Pamarisudha Desa) sehingga dipandang perlu mengadakan suatu usaha untuk meningkatkan pemasukan asli Desa Pakraman. Disini terlihat bahwa kepala desa dalam membuat suatu keputusan memperhatikan kepentingan masyarakat lokal yang dalam hal ini adalah kepentingan Desa Pakraman Padangsambian. Hal ini menandakan adanya lokalisasi kewenangan atau subsidiaritas pemerintahan desa khususnya dalam pengertian pengambilan keputusan secara lokal atas kepentingan masyarakat setempat. Dengan subsidiaritas urusan-urusan yang berskala lokal diputuskan secara lokal dengan kewenangan Desa, dan masalah-masalah lokal juga diselesaikan secara lokal. Subsidiaritas mengandung spirit menghargai, mempercayai dan menantang Desa untuk bergerak.

\section{E. Kesimpulan}

Bahwa pemerintahan desa sudah ada jauh sebelum penjajah masuk ke Indonesia, yaitu sejak zaman kerajaan-kerajaan di nusantara. Begitu juga dengan eksistensi adat dalam penyelenggaraan pemerintahan desa yang telah ada sejak lama. Eksistensi adat dalam penyelenggaraan pemerintahan desa di Bali dapat dimulai dilihat dari instrumen hukum yang mengakomodasi dan melegalkan hukum adat dalam penyelenggaraan pemerintahan desa itu sendiri. Selain itu, dapat dilihat 
dari penerapan filosofi Tri Hita Karana yang diadopsi dari ajaran agama Hindu yaitu berupa adanya pengaturan Asta Kusala Kusali berupa pengaturan tata ruang (Parahyangan), pembuatan koperasi pegawai (Pawongan) dan persyaratan sebagai calon Kepala Desa yang ditetukan oleh peraturan perundang-undangan dan harus memperhatikan nilai-nilai sosial budaya setempat. Hadirnya Desa Pakraman juga merupakan bukti nyata penghormatan dan penerapan adat dalam sistem pemerintahan desa di Bali. Adanya dua desa di Bali yaitu desa pakraman dan desa dinas, bukanlah berarti ada dikotomi desa dalam sistem pemerintahan desa di Bali melainkan saling melengkapi. Desa pakraman mengurusi bidang keagamaan dan adat, sedangkan desa dinas mengurusi bidang administrasi pemerintahan. Dengan demikian, eksistensi Desa Pakraman bukan sebagai wujud superioritas adat dalam pemerintahan desa di Bali.

\section{DAFTAR PUSTAKA}

\section{Buku}

Naskah Akademis Rancangan Undang-Undang tentang Desa (Jakarta: Direktorat Jenderal Pemberdayaan Masyarakat dan Desa Departemen Dalam Negeri, 2007).

\section{Makalah / Artikel / Prosiding / Hasil Penelitian}

Hasil wawancara dengan Dewa Eka (Kepala Biro Hukum Pemerintah Daerah Propinsi Bali) pada tanggal 14 Juni 2011.
Hasil wawwancara dengan I Made Gede Wijaya (Kepala Desa Padangsambian Kaja) pada tanggal 14 Juni 2011.

\section{Internet}

Hadin, Muhjad. "Peran dan Fungsi Kedudukan Hukum Adat dalam Sistem Hukum Nasional dalam Rangka Penguatan dan Pelestarian Nilai-nilai Adat Istiadat di Daerah", http:// www.gunungmaskab.go.id/informasi/ucapandirgahayu-ke-8-kab-gunung-mas-dari-pemprovkalteng.html. (diakses 23 April 2012).

"Hukum Adat," www.hukumhindu.com. (diakses 7 Agustus 2011).

Titib, I Made. "Desa Pakraman Wahana Pengamalan Ajaran Agama Hindu Di Bali," http://www. hukumhindu.com/2011/03/hukum-adat/. (diakses 6 Agustus 2011).

"Mengkaji Hak Masyarkat Hukum Adat di Indoensia," http://www.ilo.org/jakarta/info/public/pr/lang-en/contLang-id/WCMS_116136/index.htm. (diakses 13 September 2011).

"Bali dan Pariwisata". http://www.baliprov.go.id/ index.php?page $=69$. (diakses 13 September 2011).

\section{Peraturan}

Undang-Undang tentang Pemerintahan Daerah. UU No.32. LN No.125 Tahun 2004. TLN. No.4437.

Peraturan Pemerintah tentang Desa. PP No.72. LN No. 158 Tahun 2005. TLN. No.4587.

Peraturan Daerah Propinsi Bali tentang Kedudukan Fungsi dan Peranan Adat sebagai Kesatuan Masyarakat Hukum Adat Dalam Propinsi Daerah Tingkat I Bali. Perda Propinsi Bali No. 6 Tahun 1986.

Peraturan Daerah Propinsi Bali tentang Desa Pakraman. Perda Propinsi Bali No. 3 LD Provinsi Bali Tahun 2001 No. 29 Seri D no. 29. TLD Propinsi Bali. 